\title{
THE IN VITRO INFLUENCE OF A PHARMACEUTICALLY ACTIVE SMALL SEA FISH EXTRACT ON APOPTOSIS AND PROLIFERATION MECHANISMS AMPLIFIED BY INFLAMMATORY CONDITIONS
}

\author{
LAURA OLARIU ${ }^{1,2}$, BRINDUSA DUMITRIU ${ }^{1}$, LUIZA CRACIUN $^{1}$, EMILIA BUSE ${ }^{1}$, NATALIA \\ ROSOIU $^{2,3}$, MIHAI BOJINCA ${ }^{4 *}$, TOMA PAPACOCEA ${ }^{5}$ \\ ${ }^{I}$ S.C. Biotehnos S.A., 3-5 Gorunului Street, 075100-Otopeni, Ilfov, Romania \\ ${ }^{2}$ Academy of Romanian Scientists, 54 Splaiul Independentei 050094, Bucharest, Romania \\ ${ }^{3}$ Ovidius University, Faculty of Medicine, Department of Biochemistry, Constanța, Romania; \\ 4 "Dr. I. Cantacuzino" Hospital, Clinique of Internal Medicine and Rheumatology, Bucharest, Romania \\ 5 "Carol Davila” University of Medicine and Pharmacy, Neurosurgery Department, "St. Pantelimon” Emergency Hospital, \\ Bucharest, Romania
}

*corresponding author: vmbojinca@yahoo.com

Manuscript received: November 2017

\begin{abstract}
The osteoarthritis pathogenesis is depicted by the start of articular cartilage degradation and dysfunction in chondrocytes metabolism. Many drugs were developed in order to prevent or stop one or several pathways of osteoarthritis progression, but a therapeutically efficient solution is far from been achieved. Our research is focused on apoptotic and cell division mechanisms, dramatically changed in osteoarthritis, highlighting inflammatory conditions mimicked through two types of stimuli: IL1 $\beta$ and TNF $\alpha$. The protective action of a small sea fish extract was studied on a human chondrocytes cell line (CHON-001), comparing its action with two pharmaceutically active compounds: chondroitin sulphate and ascorbic acid. The previously demonstrated regenerating effect of the product is completed with anti-apoptotic and pro-mitotic action in pro-inflammatory stimulated chondrocytes, as well as the hyaluronic acid extracellular restoring in IL1 $\beta$ treated $\mathrm{CHON}-001$.
\end{abstract}

\section{Rezumat}

Patogeneza osteoartritică este definită de debutul degradării osteoarticulare și disfuncții în metabolismul condrocitelor. Deși s-au dezvoltat multe substanțe farmaceutice pentru prevenția sau stoparea anumitor căi de propagare a osteoartrozei, încă nu s-a ajuns la o soluție terapeutică eficientă. Cercetările noastre sunt direcționate către mecanisme apoptotice și de diviziune celulară, dramatic perturbate în osteoartroza, evidențiind condiții inflamatorii mimate de două tipuri de stimuli: IL1 $\beta$ si $\mathrm{TNF} \alpha$. Acțiunea protectoare a unui extract de pește marin mărunt a fost studiată pe o linie celulară umană de condrocite (CHON-001), comparând-se acțiunea sa cu doi compuși farmaceutic activi: sulfatul condroitină și acidul ascorbic. Efectul regenerator al produsului este completat cu acțiunea anti-apoptotică si pro-mitotică asupra condrocitelor stimulate proinflamator, precum și de refacerea acidului hialuronic din mediul extracelular al celulelor CHON-001 tratate cu IL1 $\beta$.

Keywords: apoptosis, cell cycle, hyaluronic acid, chondrocytes, inflammation, small sea fish extract

\section{Introduction}

Osteoarthritis (OA) is a disease of joints and bones that may result from multiple pathophysiological mechanisms, one of which is the dysregulation of cellular homeostasis, expressed by apoptotic rate and the sequence of cell cycle. Articular degradation becomes a major cause of disability, especially because cartilage tissue has a reduced self-healing potential being un-vascularised, and chondrocytes have a limited ability to migrate and repair the affected site [19]. Pathological chondrocytes undergo an abnormal extracellular stimulus cascade, including autocrine and paracrine factors, synovial stimuli and protein components in the altered matrix, inducing a cumulation of disrupted cellular responses at the anabolic, catabolic and phenotypic level [7, 10]. Converging in vivo signals generate perturbations in physiology of resting articular chondrocyte, including proliferation, hypertrophic differentiation, and lead to osteoarthrosis disease [4]. The morphological changes of chondrocytes in OA cartilage are attributed to apoptosis and/or chondroptosis [21].

Having multiple aetiologies, osteoarthritis is a difficult to treat pathology, usually pharmacological interventions solely addressed to chronic pain fail and do not prevent cartilage damage and the associated destruction of other joint tissues [20]. New pharmaco-therapeutic options are emerging, targeting the dysregulated molecular processes responsible for disease onset. Based on the occurrence of apoptosis in the osteoarthritic pathologies, this process could be one of the valid targets to modulate the cartilage degeneration [8]. 
FARMACIA, 2018, Vol. 66, 3

Ascorbic acid (vitamin C) is known for its role in osteogenesis, wound healing and the maintenance of healthy gums. Recent studies identified that it reduces apoptosis, reduces the loss of viability and markedly decreased $\mathrm{H}_{2} \mathrm{O}_{2}$-mediated senescence in cells treated with $\mathrm{H}_{2} \mathrm{O}_{2}$, decreased the activity of nuclear factor (erythroid-derived 2)-like 2 (NRF2), nuclear factor kappa-light-chain-enhancer of activated $\mathrm{B}$ cells $(\mathrm{NF}-\mathrm{\kappa B})$, activator protein 1 (AP1) and matrix metalloproteinase-3, which is stimulated by $\mathrm{H}_{2} \mathrm{O}_{2}[1,5,16]$. As well as, ascorbic acid stimulated the proliferation of chondrocytes and maintained the chondrogenic properties of the cells in alginate beads culture, promoted the differentiation, stimulating the formation of collagenous matrix [17].

As "in vitro" models, chondrocytes are more responsive to the chondroprotective agents, glucosamine and chondroitin sulphate [11]. They improve chondrocytes' ability to repair and regenerate. In vitro previous observations suggest that these compounds function as biological response modifiers, agents which improve the natural protective responses of tissues $[12,18]$. As a clinical treatment, glucosamine and chondroitin are nutritional supplements that act as chondroprotectors or/and as "disease-modifying osteoarthritis drugs". Although many studies have showed a significant treatment effect and remarkable safety, their relative effectiveness compared with placebo is controversial [9]. The common osteoarthritic therapy with nonsteroidal anti-inflammatory drugs (NSAIDs), is accompanied by the treatment with chondroprotectors, or nutrients such as antioxidants and omega-3 fatty acids $[3,6]$.

Our studies targeted the pro-inflammatory stimulation of chondrocytes in order to start the cellular degradation and the monitoring of apoptosis and the sequence of cell cycle as the representative parameters for the functional status. In addition, we quantified in chondrocytes the extracellular hyaluronic acid as a key macromolecule responsible for the extracellular matrix homeostasis, before and after proteolysis initiation by IL1 $\beta$. The biological action of three pharmaceutical compounds was evaluated and compared: the small sea fish extract, ascorbic acid and chondroitin sulphate. The cellular effects of the small sea fish extract have been sustained especially on matrix preservation, oxidative stress and inflammation inhibition by previous research $[13$, 14]. We designed our studies in order to complete the in vitro efficacy spectrum through apoptotic and cell division mechanisms, dramatically changed in inflammatory conditions mimicked through two types of stimuli: IL $1 \beta$ and TNF $\alpha$.

\section{Materials and Methods}

\section{Cell cultures}

Chondrocyte cell line CHON-001 (ATCC ${ }^{\circledR}$ CRL$2846^{\mathrm{TM}}$ ), human normal chondrocytes from long bone cartilage. Cultivation was performed in high glucose DMEM media, 10\% foetal bovine serum, $0.1 \mathrm{mg} / \mathrm{mL}$ G-418 antibiotic solution, at $37^{\circ} \mathrm{C}$, in $95 \%$ humidified air and $5 \% \mathrm{CO}_{2}$ incubator. After $24 \mathrm{~h}$, time for adhesion on plates, cells were treated with a small sea fish extract (CP), CS - chondroitin sulphate sodium salt/water soluble (CRS-EDQM reference substance 0000593) and vitamin $\mathrm{C} /$ water soluble (L-ascorbic acid Sigma Aldrich A92902). After a previous cytotoxicity screening, the following concentrations were selected: $\mathrm{CP} 0.2 \%$ and $0.3 \%$ (V/V in culture medium); CS $3 \mu \mathrm{g} / \mathrm{mL}$ and $200 \mu \mathrm{g} / \mathrm{mL}$ and vitamin $\mathrm{C} 45 \mu \mathrm{M}$. In order to mimic in vitro the degradative, pro-inflammatory conditions in osteoarthritis, cells were stimulated for $48 \mathrm{~h}$ and $72 \mathrm{~h}$ with IL1 $\beta 10 \mathrm{ng} / \mathrm{mL}$ and $24 \mathrm{~h}$ with TNF $\alpha 15 \mathrm{ng} / \mathrm{mL}$. Results were compared with the untreated cells (control), in a dynamic manner, after $48 \mathrm{~h}$ and $72 \mathrm{~h}$ of treatment. Chemicals and reagents: CycleTEST ${ }^{\mathrm{TM}}$ PLUS DNA Reagent (BD Pharmingen); Annexin V-FITC Apoptosis Detection Kit (BD Pharmingen); Human Hyaluronic Acid ELISA kit (Cusabio); Equipments: Flow cytometer FACS CANTO II with DIVA 6.1 and FCS Express software. Berthold TRISTAR.

Apoptosis through phosphatidil serine (PS) translocation [15]

The Annexin V-FITC, detected through flow cytometry as green fluorescence (FITC-A), is binded to PS in the membrane of cells which are beginning the apoptotic process; in cells where the membrane has been compromised propidium iodide stain the DNA and is detected as red fluorescence (PE-A).

DNA staining for flow cytometry cell cycle analysis The isolation and label of the nuclei in cell suspensions is done using Cycle TEST PLUS DNA Reagent (BD Pharmingen) [2]. PI staining of nuclear DNA shows a histogram representation of $\mathrm{G} 0 / \mathrm{G} 1, \mathrm{~S}$ and $\mathrm{G} 2 / \mathrm{M}$ cell cycle phases. Cell cycle progression is visualized by flow cytometry (Figure 1).

Extracellular hyaluronic acid was quantified through a high sensitive sandwich enzyme immunoassay using antibodies specific for hyaluronic acid (Human Hyaluronic Acid ELISA kit-CUSABIO CSB E04805h).

Statistics

Data are expressed as mean \pm standard deviation (SD), averaged over at least three independent experiments for normally distributed data. We consider $* \mathrm{p}<0.05$, $* * \mathrm{p}<0.01, * * * \mathrm{p}<0.001, * * * * \mathrm{p}<0.0001$, using Repeated Measures ANOVA, Dunnett's Multiple Comparison Test. 

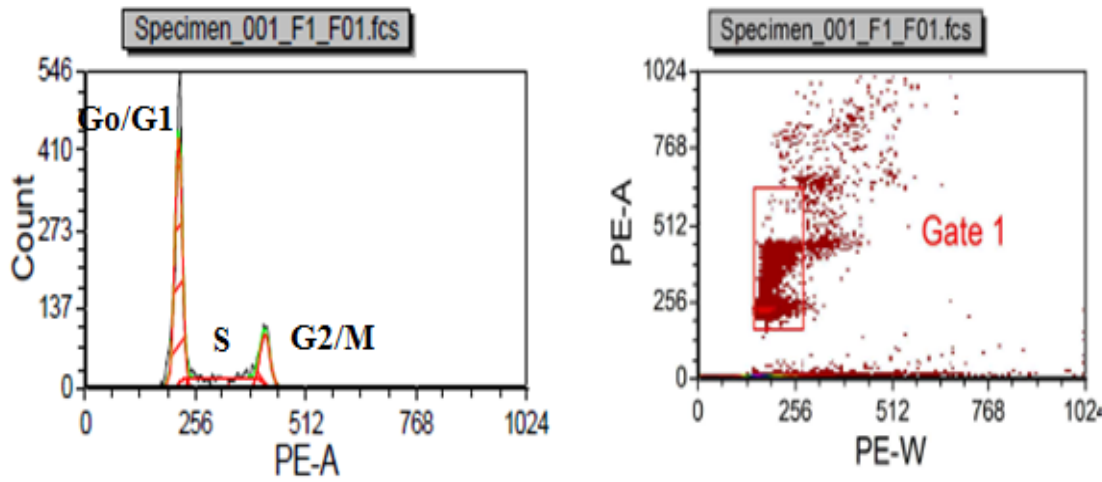

Figure 1.

Flow cytometry cell cycle monitoring

\section{Results and Discussion}

The experiments evaluated and compared the effects of small sea fish extract (CP), chondroitin sulphate (CS) and vitamin $C$. In two special stimulation conditions, specific for osteoarthritic pathology, using $\mathrm{TNF} \alpha 15 \mathrm{ng} / \mathrm{mL}$ - systemic stimuli, the main generator of pro-inflammatory cascades and IL1 $\beta 10 \mathrm{ng} / \mathrm{mL}$, as promoter for cartilage degradation through proteolytic enzymes activation. The extra-cellular matrix decline after the IL1 $\beta$ specific stimulation was checked by hyaluronic acid quantification from the supernatant of cells treated with the fish extract and vitamin C. Results showed the decrease of extracellular hyaluronic acid in stimulated chondrocytes, followed by the significant restoration of this molecule in cells treated with CP and vitamin C (Table I).

Table I

Extracellular hyaluronic acid content in IL1 $\beta$ stimulated cells; the impact of treatment with CP and vitamin C

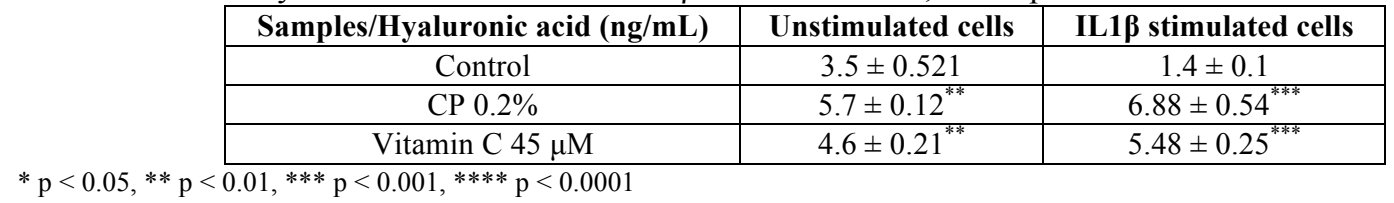

The evaluation of time - dependent apoptotic process reveals that it is installed even at $48 \mathrm{~h}$ for both stimulation conditions, more evident in IL1 $\beta$ activated chondrocytes (Figure 2, Table II).

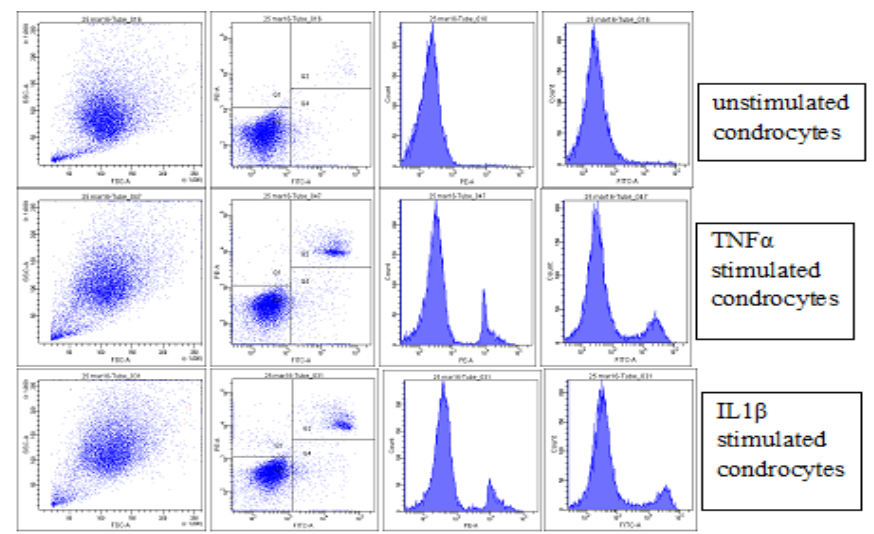

Figure 2.

Apoptosis induction on TNF $\alpha$ and IL1 $\beta$ stimulated CHON-001 chondrocytes

Chondrocytes act as the main trigger for the maintenance, organization and composition of the cartilage matrix, but there is a low percentage $(1-5 \%$ of the total volume of the cartilage) and they have a slow rate of multiplication. Stimulating them is of extreme importance for cartilage restoration, this process being a pharmaceutical target. The small changes raising the cell proliferation should be considered in respect to the general homeostasis of the cell (Table II). Results of time-dependent studies (48 h and $72 \mathrm{~h}$ ) are presented in Figure 3. 
Table II

Apoptotic and proliferative status at $48 \mathrm{~h}$ and $72 \mathrm{~h}$ of cultivation

\begin{tabular}{|c|c|c|c|}
\hline & \multicolumn{2}{|c|}{ Apoptosis evolution (after $48 \mathrm{~h}$ ) } & Cell cycle sequentiation after $48 \mathrm{~h}$ (mitotic phases) \\
\hline Unstimulated cells & Early apoptosis & Late apoptosis & $\% \mathrm{~S}+\% \mathrm{G} 2 / \mathrm{M}$ \\
\hline Control & $8.917 \pm 0.6285$ & $2.107 \pm 0.4314$ & $18.67 \pm 1.564$ \\
\hline $\mathrm{CP} 0.2 \%$ & $6.987 \pm 0.431^{* * *}$ & $1.333 \pm 0.1528^{*}$ & $28.23 \pm 6.45^{\mathrm{ns}}$ \\
\hline CP $0.3 \%$ & $8.7 \pm 0.7365^{\mathrm{ns}}$ & $2.073 \pm 0.2084^{\mathrm{ns}}$ & $32.36 \pm 15.34^{\mathrm{ns}}$ \\
\hline Vitamin C $45 \mu \mathrm{M}$ & $7.46 \pm 0.3732^{* * *}$ & $4.88 \pm 0.7279^{* * *}$ & $21.49 \pm 10.98^{\mathrm{ns}}$ \\
\hline $\mathrm{CS} 3 \mu \mathrm{g} / \mathrm{mL}$ & $8.52 \pm 0.5444^{\mathrm{ns}}$ & $1.983 \pm 0.1069^{\mathrm{ns}}$ & $22.51 \pm 12.55^{\mathrm{ns}}$ \\
\hline $\mathrm{CS} 200 \mu \mathrm{g} / \mathrm{mL}$ & $8.177 \pm 0.3742^{*}$ & $2.17 \pm 0.3799^{\mathrm{ns}}$ & $16.89 \pm 3.957^{\mathrm{ns}}$ \\
\hline \multicolumn{4}{|l|}{ IL1beta stimulation } \\
\hline Control & $11.55 \pm 1.096$ & $7.567 \pm 0.27140$ & $26.5 \pm 0.9852$ \\
\hline $\mathrm{CP} 0.2 \%$ & $11.3 \pm 1.104^{\mathrm{ns}}$ & $4.117 \pm 0.08505^{* * *}$ & $34.92 \pm 2.672^{* * * *}$ \\
\hline CP $0.3 \%$ & $8.217 \pm 0.2538^{* *}$ & $2.233 \pm 0.4944^{* * *}$ & $33.98 \pm 1.775^{* * *}$ \\
\hline Vitamin C $45 \mu \mathrm{M}$ & $9.043 \pm 0.3204^{*}$ & $5.847 \pm 0.3711^{* * *}$ & $22.86 \pm 2.215^{\mathrm{ns}}$ \\
\hline $\mathrm{CS} 3 \mu \mathrm{g} / \mathrm{mL}$ & $7.378 \pm 0.9732^{* * *}$ & $8.903 \pm 0.3496^{* * *}$ & $39.17 \pm 1.556^{* * *}$ \\
\hline $\mathrm{CS} 200 \mu \mathrm{g} / \mathrm{mL}$ & $6.319 \pm 1.309^{* * *}$ & $5.103 \pm 0.4644^{* * *}$ & $31.17 \pm 0.9283^{*}$ \\
\hline \multicolumn{4}{|l|}{ TNF alfa stimulation } \\
\hline Control & $11.48 \pm 0.09165$ & $2.1 \pm 0.1735$ & $27.21 \pm 1.54$ \\
\hline $\mathrm{CP} 0.2 \%$ & $8.267 \pm 0.38^{* * *}$ & $3.007 \pm 0.522^{*}$ & $24.92 \pm 1.614^{\mathrm{ns}}$ \\
\hline CP $0.3 \%$ & $8.27 \pm 0.1473^{* * *}$ & $2.74 \pm 0.233^{\mathrm{ns}}$ & $31.86 \pm 1.592^{* *}$ \\
\hline Vitamin C $45 \mu \mathrm{M}$ & $10.51 \pm 0.5977^{* *}$ & $6.74 \pm 0.8528^{* * *}$ & $24.06 \pm 1.861^{\mathrm{ns}}$ \\
\hline $\mathrm{CS} 3 \mu \mathrm{g} / \mathrm{mL}$ & $9.64 \pm 0.3124^{* * *}$ & $2.983 \pm 0.1106^{*}$ & $25.43 \pm 0.8523^{\mathrm{ns}}$ \\
\hline \multirow[t]{2}{*}{$\mathrm{CS} 200 \mu \mathrm{g} / \mathrm{mL}$} & $12.28 \pm 0.5444^{*}$ & $4.167 \pm 0.2706^{* * *}$ & $27.52 \pm 2.36^{\mathrm{ns}}$ \\
\hline & \multicolumn{2}{|c|}{ Apoptosis evolution (after $72 \mathrm{~h}$ ) } & Cell cycle sequentiation after $72 \mathrm{~h}$ (mitotic phases) \\
\hline Unstimulated cells & Early apoptosis & Late apoptosis & $\% \mathrm{~S}+\% \mathrm{G} 2 / \mathrm{M}$ \\
\hline Control & $6.633 \pm 3.932$ & $2.07 \pm 0.6807$ & $19.24 \pm 1.146$ \\
\hline $\mathrm{CP} 0.2 \%$ & $6.133 \pm 1.358^{\mathrm{ns}}$ & $1.50 \pm 0.3^{\mathrm{ns}}$ & $26.81 \pm 0.7641^{* * *}$ \\
\hline CP $0.3 \%$ & $7.767 \pm 1.804^{\mathrm{ns}}$ & $1.73 \pm 0.8145^{\mathrm{ns}}$ & $25.42 \pm 1.682^{* * *}$ \\
\hline Vitamin C $45 \mu \mathrm{M}$ & $5.8 \pm 2.261^{\mathrm{ns}}$ & $4.17 \pm 2.318^{\mathrm{ns}}$ & $11.65 \pm 1.123^{* * *}$ \\
\hline $\mathrm{CS} 3 \mu \mathrm{g} / \mathrm{mL}$ & $7.967 \pm 1.102^{\mathrm{ns}}$ & $3.73 \pm 3.004^{\mathrm{ns}}$ & $11.69 \pm 0.8065^{* * *}$ \\
\hline $\mathrm{CS} 200 \mu \mathrm{g} / \mathrm{mL}$ & $6.6 \pm 2.291^{\mathrm{ns}}$ & $1.80 \pm 1.058^{\mathrm{ns}}$ & $13.79 \pm 1.489^{* *}$ \\
\hline \multicolumn{4}{|l|}{ IL1 beta stimulation } \\
\hline Control & $9.33 \pm 0.8737^{\mathrm{ns}}$ & $5.77 \pm 3.591$ & $16.95 \pm 1.424$ \\
\hline CP $0.2 \%$ & $9.10 \pm 4.967^{\mathrm{ns}}$ & $3.10 \pm 1.345^{\mathrm{ns}}$ & $26.63 \pm 1.831^{* * *}$ \\
\hline CP $0.3 \%$ & $6.43 \pm 2.538^{\mathrm{ns}}$ & $2.10 \pm 0.9644^{* *}$ & $31.00 \pm 1.213^{* * *}$ \\
\hline Vitamin C $45 \mu \mathrm{M}$ & $6.93 \pm 3.443^{\mathrm{ns}}$ & $4.60 \pm 2.433^{\mathrm{ns}}$ & $15.79 \pm 1.341^{\mathrm{ns}}$ \\
\hline $\mathrm{CS} 3 \mu \mathrm{g} / \mathrm{mL}$ & $10.00 \pm 3.329^{\mathrm{ns}}$ & $7.77 \pm 2.003^{\mathrm{ns}}$ & $19.77 \pm 1.115^{\mathrm{ns}}$ \\
\hline $\mathrm{CS} 200 \mu \mathrm{g} / \mathrm{mL}$ & $8.63 \pm 4.038^{\mathrm{ns}}$ & $4.70 \pm 0.8185^{\mathrm{ns}}$ & $16.31 \pm 1.075^{\mathrm{ns}}$ \\
\hline \multicolumn{4}{|l|}{ TNF alfa stimulation } \\
\hline Control & $12.27 \pm 3.349$ & $3.17 \pm 1.704$ & $13.90 \pm 1.28$ \\
\hline $\mathrm{CP} 0.2 \%$ & $6.33 \pm 2.631^{* *}$ & $2.53 \pm 1.193^{\mathrm{ns}}$ & $27.77 \pm 1.37^{* * *}$ \\
\hline CP $0.3 \%$ & $6.53 \pm 2.139^{* *}$ & $2.17 \pm 1.115^{\mathrm{ns}}$ & $26.73 \pm 2.11^{* * *}$ \\
\hline Vitamin C $45 \mu \mathrm{M}$ & $11.07 \pm 1.106^{\mathrm{ns}}$ & $5.80 \pm 2.869^{*}$ & $14.36 \pm 1.12^{\mathrm{ns}}$ \\
\hline $\mathrm{CS} 3 \mu \mathrm{g} / \mathrm{mL}$ & $10.60 \pm 1.992^{\mathrm{ns}}$ & $3.40 \pm 1.562^{\mathrm{ns}}$ & $15.62 \pm 0.63^{\mathrm{ns}}$ \\
\hline $\mathrm{CS} 200 \mu \mathrm{g} / \mathrm{mL}$ & $11.63 \pm 2.212^{\mathrm{ns}}$ & $4.57 \pm 2.732^{\mathrm{ns}}$ & $16.35 \pm 1.51^{\mathrm{ns}}$ \\
\hline
\end{tabular}

Even the IL1 $\beta$ impact is mandatory for the start of the apoptotic process, and enzymatic degradation of extracellular matrix, chondrocytes developed protective mechanisms in order to accelerate the cellular multiplication (the mitotic rate is augmented). As well as, in the case of TNF $\alpha$ stimulation that acts on different pathways of inflammation progression, chondrocytes become apoptotic but $48 \mathrm{~h}$ of treatment are not enough to disturb the cell cycle sequence. The apoptotic process is significantly modulated by the bioactive compounds ( $\mathrm{CP}$, vitamin $\mathrm{C}, \mathrm{CS})$ at $48 \mathrm{~h}$ in both pro-inflammatory conditions. After $72 \mathrm{~h}$ of in vitro treatment, there are more apoptotic chondrocytes and the cell division declines. The CP compound stimulates proliferation in a significant manner in both pro-inflammatory states; in correlation with the decrease of apoptosis (late apoptosis in IL1 $\beta$ stimulatory condition and early apoptosis in $\mathrm{TNF} \alpha$ stimulated cells) indicates a protective role against degradation in osteoarthritis in response to proinflammatory agents. The other compounds (CS and vitamin C) did not significantly change the proliferative nor the apoptotic status at $72 \mathrm{~h}$. 

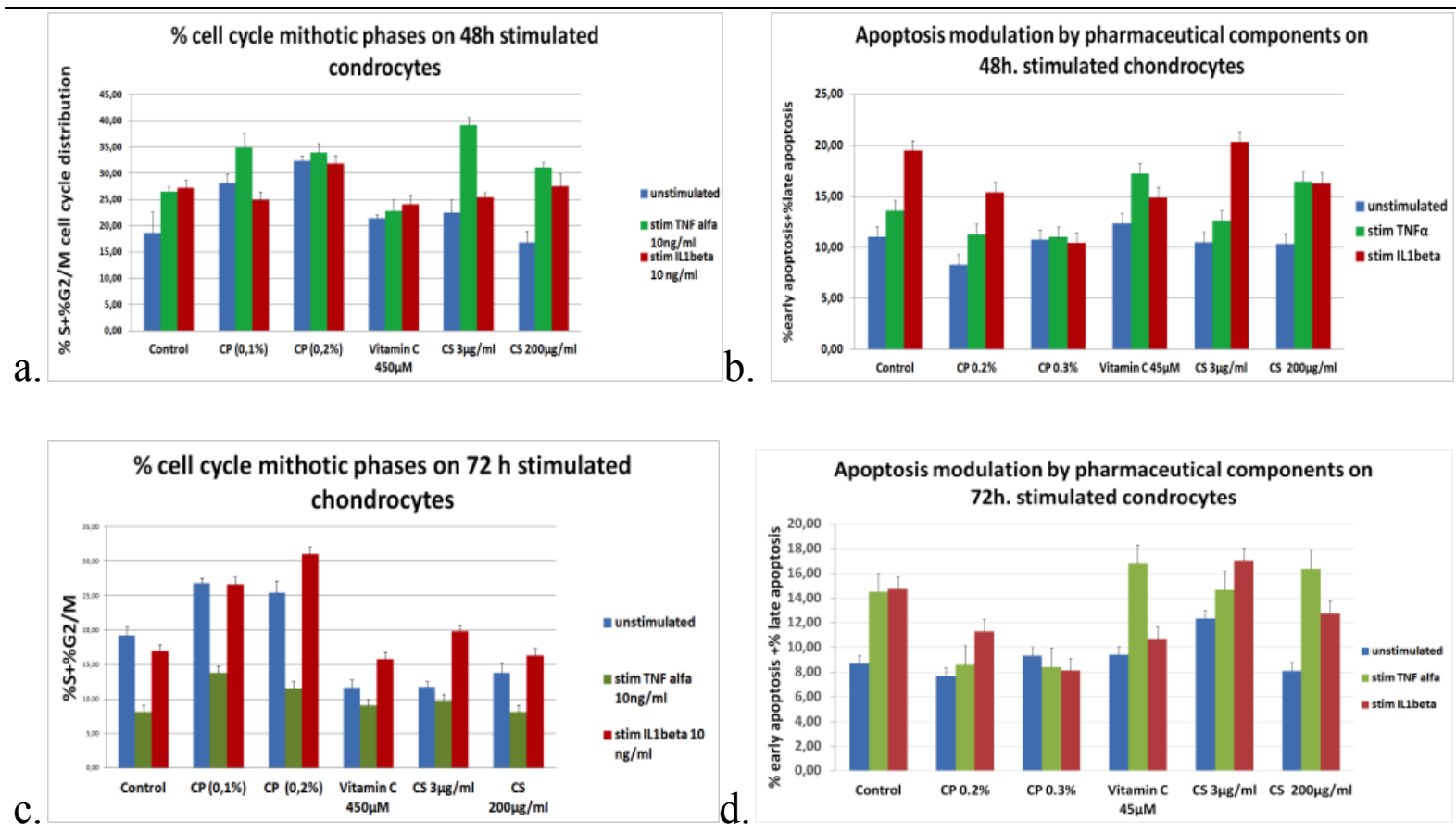

Figure 3.

a. Mitotic phases evolution on $48 \mathrm{~h}$ stimulated chondrocytes treated with bioactive compounds; $\mathrm{b}$. Apoptosis evolution on $48 \mathrm{~h}$ stimulated chondrocytes treated with bioactive compounds; c. Mitotic phases evolution on $72 \mathrm{~h}$ stimulated chondrocytes treated with bioactive compounds; d. Apoptosis evolution on $72 \mathrm{~h}$ stimulated chondrocytes treated with bioactive compounds

\section{Conclusions}

Considering the fact that the common biomolecular mechanisms of osteoarthritis is complicated and not yet revealed, we consider our studies as a step forward in the understanding of apoptotic and proliferative mechanisms related with chondrocytes inflammation, more specific with IL1 $\beta$ directed cascades and TNF $\alpha$ systemic stimulation. After 48 hours of stimulation, intrinsec protective mechanisms act to stimulate proliferation, but over time $(72 \mathrm{~h})$ they are outdated by long-term pro-inflammatory signalling in the sense of decreasing the mitotic rate. In the particular conditions of IL $1 \beta$ and TNF $\alpha$ stimulation, it was highlighted the pharmaceutical potency of natural raw materials, in our case pointing out the small sea fish extract that effectively counteracted the chondrocytes decline, both through apoptosis inhibition and stimulation of the proliferation rate. Vitamin C inhibits apoptosis only on IL1 $\beta$ stimulated cells, chondroitin sulphate stimulates the mitotic phases only when the systemic inflammation is installed (TNF $\alpha$ treated chondrocytes). Together with its stimulatory effect on hyaluronic acid production and our previous results describing the antioxidant, regenerative and matrix-preserving action, we can conclude that through the modulation of multiple regulatory pathways, the small sea fish extract efficiently protects human chondrocytes against damage induced by osteo-articular inflammation.

\section{Disclosure}

The producers of Alflutop ${ }^{\circledR}$ (S.C. Biotehnos S.A.) did not interfere with this study (data collection or processing, concluding results or editing endeavours).

\section{References}

1. Chang Z, Huo L, Li P, Wu Y, Zhang P, Ascorbic acid provides protection for human chondrocytes against oxidative stress. Mol Med Rep., 2015; 12(5): 7086-7092.

2. Dumitriu B, Olariu L, Ene MD, Zglimbea L, Rosoiu $\mathrm{N}$, The photo-protective activity of Crataegus monogyna extract proved by complementary mechanisms of skin inflammation, damage of extracellular matrix, cellular survival and proliferation disorders. Int J Biotech Wellness Ind., 2012; 1: 177-188.

3. EULAR Recommendations 2003: an evidence based approach to the management of knee osteoarthritis: Report of a Task Force of the Standing Committee for International Clinical Studies Including Therapeutic Trials (ESCISIT). Ann Rheum Dis., 2003; 62: 1145 1155.

4. Goldring MB, Otero M, Plumb DA, Dragomir C, Favero M, Hachem KE, Hashimoto K, Roach HI, Olivotto E, Borzì RM, Marcu B, Roles of inflammatory and anabolic cytokines in cartilage metabolism. Eur Cell Mater., 2011; 21: 202-220.

5. Gonhyung K, Masahiro O, Darko B, Ishiguro T, Park $\mathrm{CH}$, Kadosawa T, Fujinaga T, Effects of ascorbic acid on proliferation and biological properties of bovine chondrocytes in alginate beads. Japanese Journal of Veterinary Research, 2006; 51(2): 83-94. 
6. Hochberg MC, Altman RD, April KT, American College of Rheumatology 2012 recommendations for the use of nonpharmacologic and pharmacologic therapies in osteoarthritis of the hand, hip, and knee. Arthritis Care Res., 2012; 64(4): 465-474.

7. Husa M, Liu-Bryan Ru, Terkeltaub R, Shifting HIFs in osteoarthritis. Nature Medicine, 2010; 16: 641-644.

8. Hyun SH, Hyun AK, Chondrocyte apoptosis in the pathogenesis of osteoarthritis. Int J Mol Sci., 2015; 16(11): 26035-26054.

9. Jerosch J, effects of glucosamine and chondroitin sulfate on cartilage metabolism in OA: outlook on other nutrient partners especially omega-3 fatty acids. Int J Rheumatology, 2011; 2011: 1-17.

10. Kondo M, Yamaoka K, Tanaka Y, Acquiring chondrocyte phenotype from human mesenchymal stem cells under inflammatory conditions. Int $\mathrm{J} \mathrm{Mol}$ Sci., 2014; 15(11): 21270-21285.

11. Lippiello L, Glucosamine and chondroitin sulfate: biological response modifiers of chondrocytes under simulated conditions of joint stress. Osteoarthritis Cartilage, 2003; 11(5): 335-342.

12. Mihai L, Mitrea N, Papacocea R, Badarau AI, Dynamic activity of some antioxidant enzymes in primary cultures of neurons under hypoxia and ischemia. Farmacia, 2012; 60(1): 49-57.

13. Olariu L, Pyatigorskaya N, Dumitriu B, Pavlov A, Vacaru AM, Vacaru A, "In vitro" chondro-restitutive capacity of Alflutop ${ }^{\circledR}$ proved on chondrocytes cultures. Romanian Biotechnological Letters, 2016; 22(16): 12047-12053.
14. Olariu L, Dumitriu B, Ene DM, Pavlov A, Pyatigorskaya N, Rosoiu N, Alflutop ${ }^{\circledR}$ modulates "in vitro" relevant mechanisms of osteoarthritic pathology. Academy of Romanian Scientists, Annals Series on Biological Sciences, 2017, 6(1): 100-113.

15. Olariu L, Dumitriu B, Ene DM, Buse E, Rosoiu N, Advanced methods for antitumoral screening applied on pharmaceutical product development. Academy of Romanian Scientists, Annals Series on Biological Sciences, 2013; 2(2): 51-82.

16. Pavel IZ, Pârvu AE, Dehelean CA, Vlase L, Csuk $\mathrm{R}$, Muntean DM, Assessment of the antioxidant effect of a maslinic acid derivative in an experimental model of acute inflammation. Farmacia, 2017; 65(3): 390-395.

17. Temu TM, Wu KY, Gruppuso PA, Phornphutkul C, The mechanism of ascorbic acid-induced differentiation of ATDC5 chondrogenic cells. Am $J$ Physiol Endocrinol Metab., 2010; 299(2): 325-334.

18. Vasiliadis HS, Tsikopoulos K, Glucosamine and chondroitin for the treatment of osteoarthritis. World J Orthop., 2017, 8(1): 1-11.

19. Venezian R, Shenker BJ, Datar S, Leboy PS, Modulation of chondrocyte proliferation by ascorbic acid and BMP-2. J Cell Physiol., 1998; 174(3): 331-341.

20. Wieland HA, Michaelis M, Kirschbaum BJ, Rudolphi KA, Osteoarthritis - an untreatable disease?. Nature Reviews Drug Discovery, 2005; 4: 331-344.

21. Zamli Z, Sharif M, Chondrocyte apoptosis: a cause or consequence of osteoarthritis. Int J Rheum Dis., 2011; 14(2): 159-166. 